\title{
ФОРМУВАННЯ ІННОВАЦІЙНОЇ СТРАТЕГІЇ ПЕРЕДАТЕСТАЦІЙНОЇ ПІДГОТОВКИ ЛІКАРІВ НА ОСНОВІ СУЧАСНИХ НR-ТЕХНОЛОГІЙ
}

\author{
В. Й. Лисенко, С. В. Лисенко \\ Харківська медична академія післядипломної освіти, \\ Міжрегіональна академія управління персоналом, Харківський інститут
}

\section{MODERN HR-TECHNOLOGIES ARE INNOVATION STRATEGIES OF DOCTOR'S PRE-ASSESMENT PREPARATION}

\author{
V. Y. Lysenko, S. V. Lysenko \\ Kharkiv Medical Academy of Post-Graduate Education, \\ Inter-regional Academy of Personnel Management, Kharkiv Institute
}

\begin{abstract}
У статті пропонусться на основі HR-технологій змінити зміст передатестаційної підготовки. В якості інновації пропонується грейдінг - проведення оцінки і ранжування категорій та посад лікарів.
\end{abstract}

The article suggests on the basis of HR-technology to change the content of pre-assessment preparation. As an innovation it was proposed grading - assessment and ranging posts of doctors.

Єдине, щзо заважає моєму навчанню, - моя освіта.

А. Ейнштейн

Вступ. Медична освіта - це безперервний процес, який залежить від стану середовища, в якому розвивається людина, та ііі індивідуальної творчості. Організація європейського освітнього простору за болонськими домовленостями має на меті збільшення конкурентоспроможності української освіти, яка б була привабливою для світу. Не слід забувати, що Болонський процес - це не тільки впровадження кредитно-модульної системи, а також використання сучасних HR (Human Resources)-технологій, які пов'язані з розвитком, навчанням, будуванням кар'єри та систем мотивації. Такі технології слугують наріжним каменем управління персоналом в будь-якій сфері і потребують ширшого впровадження у сферу медичної освіти всіх рівнів та загалом у медицину. Праця медичного працівника потребує гуманізації: подальшого покращення матеріального та нематеріального стимулювання для ефективного підвищення кваліфікації лікарів.

Основна частина. У зв'язку з подальшою інтелектуалізацією медицини, основною проблемою стає формування та цілеспрямоване керівництво творчим потенціалом сучасних медичних закладів. Аналіз методів і засобів менеджменту інтелектуальних процесів показав, що вони, в основному, зводяться до (c) В. Й. Лисенко, С. В. Лисенко врахування соціально-психологічних факторів. Однак це залишає поза увагою основні творчі характеристики співробітників - носіїв, авторів та виконавців перетворень, необхідних для задоволення сучасних потреб у медицині.

Зараз вже широко визнається той факт, що не стільки матеріально-фінансові, скільки інтелектуальні ресурси визначають рівень установи. Фахівець стає важливішим за виробничі ресурси і цінується тим більше, чим більші позитивні зміни може вносити за один і той же час у предмет своєї праці. Професійний талант лікаря стає економічною категорією і виявляється в максимальних змінах, які він вносить у продукт своєїпраці за мінімальний конкурентноздатний час.

За сучасного стану економіки ця обставина $€$ вирішальною, оскільки, за кінцевим рахунком, рівень прояву таланту (креативної чи творчої енергії) характеризує економічну сутність використання інтелектуальних ресурсів. Тільки креативна складова інтелектуальних ресурсів здатна забезпечити досягнення як суспільної, так і економічної мети в медицині. Щоб ефективно керувати інтелектуальними ресурсами, необхідно володіти інформацією про інтелектуальний капітал кожного співробітника. Для цього у всіх медичних закладах має бути створений банк даних інтелектуальних ресурсів, який включає в себе багаторівневу інформацію про професійні інтелектуально-креативні здібності кожного лікаря. 
Передатестаційний цикл (ПАЦ) має стати системним інструментом управління розвитком і використанням інтелектуального потенціалу лікаря.

На часі зробити ПАЦ частиною моніторингу професійного і посадового розвитку лікарів, додавши як складову прогнозування та управління просуванням лікаря, проектуючи рівнозначні моделі професійного і службового зростання. Щоб оцінити кожного працюючого, необхідно задіяти основні положення аксіології - науки, яка вивчає співвідношення між результатами пізнання та ̈̈х оцінкою. Будь-яка дія, процес, вчинок людини можуть бути об'єктом оцінки і змістом цінності. Оцінка потенціалу відрізняється від формальної атестації тим, щоз'ясовує реальний внесок у справу, професійніякості, базові цінності, негативні імперативи, а не тільки оцінює категорію працівника. Дані про те, наскільки ефективно працівник використовує свої професійні навички, кваліфікацію-складають його цінність.

Атестація в тому вигляді, в якому вона є зараз у медицині, перестає бути мотивуючим чинником. Цьому сприяє розмитість тарифних сіток, групи посад, що об'єднані в одну категорію оплати, іноді значно відмінні за складністю роботи. Атестація має набути нового змісту, з використанням сучасних HRтехнологій. Основою атестації може стати грейдінг (система процедур з проведення оцінки і ранжування категорій та посад). Кожна категорія поєднується

\footnotetext{
Література

1. Колпаков В. М. Маркетинг персоналу / В. М. Колпаков. -К., 2006.-C. 23-27.

2. Лысенко С. В. Аксиологический потенциал личности лидера в современном обществе / С. В. Лысенко // Збірник наукових праць учасників конференції “Теорія та практика лідерства у сучасному суспільстві”. - Донецьк : Норд-Прес, 2009. - C. 389-392.

3. Мельников О. Н. Неоплаченное богатство. Новые принципы управления трудовыми ресурсами предприятия /
}

в один грейд (клас) і має свою оплату. Кількість грейдів іноді сягає 7 і більше. Грейдінг використовує бізнес, але бюджетна сфера також потребує такої інновації, тому що має всього три категорії лікарів. Процесу грейдінгу може допомогти створення інтелектуально-креативної картки лікаря періодичною експертною оцінкою в процесі проходження ним ПАЦ. Картка може вміщувати оцінку теоретичних знань, практичних навичок, коефіцієнтів творчої енергії, а також оцінку аксіологічного потенціалу лікаря. За результатами проходження ПАЦ, розроблення персональних професійних інтелектуально-креативних карток курсантів, які оцінюють здібності кожного 3 урахуванням розширення кола діяльності, а не тільки іспиту, можливо віднести лікаря до одного з грейдів.

Розробка моделі інтелектуально-креативної картки лікаря-курсанта дозволить запустити пілотний проект “Встановлення аксіологічного потенціалу лікаря як базису для грейдінгу”.

Висновки: 1. Основою атестації лікарів повинен стати грейдінг як система проведення оцінки і ранжирування категорій та посад.

2. Необхідно розробити інтелектуально-креативну картку лікаря в процесі проходження ним ПАЦ на кафедрах академій післядипломної освіти.

3. Диференційована оплата може базуватися на основі індивідуально встановлених грейдів.

О. Н. Мельников// Российскоепредпринимательство.-2001.№ 8 .

4. Перестройка учебного процесса на последипломном этапе соответственно Болонскому процессу / А. Н. Хвисюк, В. Г. Марченко [и соавт.] // Мед. образование XXI века : сб. мат. V Междунар. научно-практической конференции, посвященной 75-летию DUVE и 50-летию фармацевтического факультета. - Витебск, 2009. - С. 431-432. 